\title{
Effect of wormshaft speed and moisture content on oil and cake qualities of expelled sesame seed
}

\author{
TMA Olayanju \\ Federal Institute of Industrial Research, Oshodi, PMB 21023 Ikeja, Lagos, Nigeria (tiyanju@yahoo.com)
}

\begin{abstract}
For processing two sesame seed accessions, Yandev 55 and E8, in an oil expeller, a wormshaft speed of $45 \mathrm{rpm}$ and $5.3 \%$ seed moisture content gave the best oil and cake qualities.
\end{abstract}

Keywords: sesame, expeller, oil, wormshaft speed, moisture content.

\section{Introduction}

Sesame (Beniseed, Sesamum indicum) is an excellent source of oil and protein. It is free from antinutritional factors (Share 1998), unlike many oilseeds, and the oil contains the antioxidants sesamol and tocopherol which make it resistant to oxidative rancidity (Yen and Shyu 1989). The performance of oil expellers is affected by the operational parameters and seed moisture content (Sivakumaran and Goodrum 1987; Vadke and Sasulski 1988). However, there is little published information on the optimum conditions for sesame seed. This paper concerns the processing of two accessions, Yandev 55 and E8, commonly grown in Nigeria.

\section{Materials and methods}

Fifty $\mathrm{kg}$ of each accession were cleaned using a specific gravity separator to remove dust, sand, dry leaves and empty capsules. Samples were dehulled in a mechanical dehuller consisting of three blades rotating in a container of excess water (Olayanju et al. 2000). Seeds were separated from hulls in $15 \%$ brine, when the hulls sink while the seeds float. The moisture content was determined by drying at $105^{\circ} \mathrm{C}$ for hand adjustment to 4.10 , 5.31, 7.69 and $10.32 \%$ (Kachru et al. 1994). Dehulled samples (2 kg) were processed in an expeller with capacity of $10 \mathrm{~kg} / \mathrm{h}$, an expression chamber $60 \mathrm{~mm}$ in diameter and a wormshaft $600 \mathrm{~mm}$ long, powered by $0.75 \mathrm{~kW}$ reduction motor. The expressed oil was clarified in a filter press.

The specific gravity of the oil was determined using a density bottle, and the free fatty acid content by the AOAC (1984) method. The protein content of the cake was determined by the macro Kjeldahl method (AOAC 1984) and the residual oil by Soxhlet extraction with n-hexane. Three experiments were conducted using four wormshaft speeds as main plot with moisture content as subplot and accession as the sub-subplot. 


\section{Results and discussion}

The colour of the oil darkened as the wormshaft speed increased from 30 to $75 \mathrm{rpm}$ and with higher initial moisture content (Table 1). All the oil colours were within the standard for crude oils (Rosell and Pritchard 1991). The residual oil in the cake increased with higher moisture contents. The lowest residual oil was obtained at $45 \mathrm{rpm}$ and moisture content of $5.3 \%$ for both accessions. Similar trends were reported by Tikko et al. (1985) for a different expeller and by Sivakumaran and Goodrum (1987) for a screw press.

The relative density of the expressed oil was 0.915-0.923, within the range specified for sesame seed oil by the Codex Alimentarius (1992) and the free fatty acid values (0.84 and 0.98) were below the level of $1.01 \%$ specified by Johnson et al. (1979).

\section{Acknowledgements}

We thank Mr H Crowbar of AfriAgric Products Ltd and Mrs MO Oresanya for her assistance.

\section{References}

AOAC (1984) Official method of analysis, 11th edn. Washington, DC: Association of Official Analytical Chemists. Codex Alimentarius (1992) Standard for edible sesame seed oil. Fats, Oils and Related Products 8: 33-36.

Johnson LA, Suleiman JM and Lusas EW (1979) Sesame protein: a review and prospectus. Journal of the American Oil Chemist's Society 56.

Kachru RP, Gupta RK and Alam A (1994) Physicochemical constituents and engineering properties of food crops. Jodhpur, India: Scientific Publishers.

Table 1. Effect of wormshaft speed and moisture content of two sesame seed accessions

\begin{tabular}{|c|c|c|c|c|c|c|c|}
\hline \multirow[t]{2}{*}{$\begin{array}{l}\text { Wormshaft } \\
\text { Speed (rpm) }\end{array}$} & \multirow[t]{2}{*}{$\begin{array}{l}\text { Moisture } \\
\text { content } \\
(\%, w b)\end{array}$} & \multicolumn{2}{|c|}{$\begin{array}{l}\text { Residual oil } \\
\text { in cake }(\%)\end{array}$} & \multicolumn{2}{|c|}{$\begin{array}{l}\text { Residual } \\
\text { moisture in } \\
\text { cake }(\%)\end{array}$} & \multicolumn{2}{|c|}{ Colour of oil } \\
\hline & & Yandev 55 & E8 & Yandev 55 & E8 & Yandev 55 & E8 \\
\hline 30 & 4.10 & 40.4 & 42.8 & 3.30 & 3.52 & Light & Light \\
\hline 30 & 5.31 & 37.3 & 36.1 & 4.60 & 4.64 & Light & Yellow \\
\hline 30 & 7.69 & 37.9 & 37.6 & 6.05 & 6.25 & Yellow & Yellow \\
\hline 30 & 10.32 & 42.2 & 42.3 & 6.22 & 7.09 & Light & Light \\
\hline 45 & 4.10 & 20.0 & 23.6 & 3.20 & 3.39 & Light & Light \\
\hline 45 & 5.31 & 14.4 & 17.7 & 4.60 & 4.60 & Golden & Golden \\
\hline 45 & 7.69 & 22.7 & 25.6 & 6.16 & 6.18 & Golden & Golden \\
\hline 45 & 10.32 & 27.1 & 27.1 & 6.44 & 6.52 & Yellow & Light \\
\hline 60 & 4.10 & 32.2 & 32.8 & 3.20 & 3.38 & Light & Light \\
\hline 60 & 5.31 & 29.7 & 31.1 & 4.65 & 4.68 & Golden & Golden \\
\hline 60 & 7.69 & 36.8 & 37.0 & 6.18 & 6.21 & Golden & Light \\
\hline 60 & 10.32 & 37.0 & 39.4 & 6.68 & 6.59 & Light & Golden \\
\hline 75 & 4.10 & 38.8 & 39.6 & 3.30 & 3.55 & Light & Light \\
\hline 75 & 5.31 & 38.0 & 38.5 & 3.30 & 3.57 & Light & Light \\
\hline 75 & 7.69 & 43.3 & 43.5 & 6.16 & 6.19 & Light & Yellow \\
\hline 75 & 10.32 & 43.5 & 43.9 & 6.70 & 6.73 & Yellow & Yellow \\
\hline
\end{tabular}


Olayanju TMA, Oresanya MO and Adeagbo AA (2000) Development of a processing plant for beniseed. Proceedings 1st International Conference of the Nigerian Institution of Agricultural Engineers, vol. 22, pp. 48-51.

Rosell JB and Pritchard JLR (1991) Analysis of oilseeds, fats and fatty food. New York: Elsevier Applied Science.

Share SK (1998) Anti nutritional factors in oilseeds. In: Processing and storage of oilseeds and products for food uses. Bhopal, India: Central Institute of Agricultural Engineering, pp. 211-218.

Sivakumaran K and Goodrum JW (1987) Influence of internal pressure on performance of a small screw expeller. Transactions of the American Society of Agricultural Engineers 30: 1167-1171.

Tikko AK, Gupta DK and Singh BPN (1985) Cold pressing of rapeseed. Research Bulletin Pant Nagar Institute of Technology, India.

Vadke VS and Sasulski FW (1988) Mechanics of oil expression from canola. Journal of the American Oil Chemists' Society 65: 1169-1176.

Yen GC and Shyu SL (1989) Oxidative stability of sesame oil prepared from sesame seed with different roasting temperature. Food Chemistry 34: 215-224. 